\title{
Regulation of sodium in the shore crab Carcinus maenas, adapted to environments of constant and changing salinities
}

\author{
D. Siebers, A. Winkler, K. Leweck \& A. Madian \\ Biologische Anstalt Helgoland (Zentrale); \\ Notkestr. 31, D-2000 Hamburg 52, Federal Republic of Germany
}

\begin{abstract}
The activity of Na-K-ATPase was determined in the posterior gills of the shore crab Carcinus maenas during a period following transfer from 35 to $10 \%$ salinity and vice versa at $15^{\circ} \mathrm{C}$. After transfer from high to low salinity, Na-K-ATPase activity increased from 3.2 to $7.0 \mu$ moles $P_{i} \mathrm{mg}$ protein ${ }^{-1} \mathbf{h}^{-1}$ within a period of 2 to 3 weeks. Transfer of crabs from low to high salinity resulted in reduction of activity from 7.4 to $4.5 \mu$ moles $P_{\mathrm{i}} \mathrm{mg}$ protein ${ }^{-1} \mathrm{~h}^{-1}$ within about the same period. The relatively slow response following salinity change indicates that the amounts of Na-K-ATPase in the gills may play a role in hyperionic Na regulation in relatively constant brackish-water environments. Instant responses to salinity result from activation and inhibition of Na-K-ATPase activity by Na. Gill Na-K-ATPase is activated by the Na concentration of the incubation medium to attain a steep maximum at about $75 \mathrm{mM} \mathrm{Na}$, which corresponds to the lowest environmental $\mathrm{Na}$ levels tolerated by C. maenas equivalent to a salinity of ca $6 \%$. Activity greatly decreased towards higher $\mathrm{Na}$ levels, equivalent to the salinity of normal sea water, at which hyperregulation no longer occurs. Selective addition of either $\mathrm{Na}$ or $\mathrm{Cl}$ to brackish water of $9 \% \mathrm{~S}$ resulted in effective hyperregulation of the non-increased ion, and passive distribution between medium and blood of the increased ion. These data indicate that under appropriate conditions the normally coupled transport of $\mathrm{Na}$ and $\mathrm{Cl}$ may be uncoupled and take place independently of each other.
\end{abstract}

\section{INTRODUCTION}

The shore crab Carcinus maenas belongs to the few marine decapods capable of inhabiting brackish waters of salinities as low as $8 \%$, and tidal estuaries with salinity changes twice daily. Successful colonization of dilute media depends on the ability of the shore crab to hyperregulate osmolality and ionic constituents of the body fluids, thus withstanding dilution by the external medium.

In a previous communication (Siebers et al., 1982), it was shown that in $C$. maenas the gills are the main organs of ionic regulation, and that the Na-K-ATPase located in the basolateral membranes of gill epithelial cells may play a central role in Na uptake in crabs adapted to dilute media. These conclusions were based on findings that the proportion of Na-K-ATPase amounted to ca 70 to $80 \%$ of total ATPases in gills, and only to about 20 to $40 \%$ in any of the other organs investigated, among them muscles, gonads, heart, hypodermis and digestive gland. Activity of the monovalent cation pump 
was salinity-dependent in gills only, showing highest activity levels in the lowest salinity tested $(10 \%)$ and vice versa.

The present paper deals with the dynamics of Na-K-ATPase activity following a change in ambient salinity. In addition, we report on the control of activity of the monovalent cation pump in media with constant and fluctuating salinities.

Finally, data are presented concerning the regulation of $\mathrm{Ca}$ and $\mathrm{Mg}$, and potential coupling of active uptake of $\mathrm{Na}$ and $\mathrm{Cl}$.

\section{MATERIALS AND METHODS}

\section{Collection and maintenance of shore crabs}

Male specimens of the shore crab Carcinus maenas $\mathrm{L}$. were collected by fishermen near the island of Helgoland, North Sea. Before use they were maintained at $15^{\circ} \mathrm{C}$ in 200-l tanks of permanently gravel-filtered seawater of $35 \% \mathrm{~S}$ and brackish water of $10 \% \mathrm{~S}$. We avoided moulting of the experimental crabs by use of individuals between 40 and $60 \mathrm{~g}$ fresh weight, which under normal conditions moult only once a year, and by exposure to short daylengths of only 6 hours light per day. The crabs were fed twice a week with pieces of the mussel Mytilus edulis and bovine heart. They remained unfed for two days prior to experiments.

\section{Activity of the Na-K-ATPase}

Preparation procedures for gill homogenates and the coupled assay for determination of the Na-K-ATPase activity, which follows the reaction scheme:

$$
\begin{array}{rl}
\mathrm{ATP} & \longrightarrow \mathrm{ADP}+\mathrm{P}_{\mathrm{i}} \\
\mathrm{ADP}+\mathrm{PEP} & \mathrm{Pk} \mathrm{Mg} \longrightarrow \mathrm{ATP}+\text { pyruvate } \\
\text { pyruvate }+\mathrm{NADH} & \stackrel{\mathrm{LDH} \longrightarrow \text { lactate }+ \text { NAD }}{ }
\end{array}
$$

were published earlier (Siebers et al., 1982). In experiments concerning Na-dependence of Na-K-ATPase, we used the ammonium salt of ATP instead of the Na-salt (Sigma). It was obtained from the barium salt of ATP (Sigma) by addition of an equimolar amount of $\left(\mathrm{NH}_{4}\right)_{2} \mathrm{SO}_{4}$, followed by centrifugation of $\mathrm{BaSO}_{4}$. In addition, $\mathrm{Na}$-dependence of $\mathrm{Na}-\mathrm{K}$-ATPase activity was determined by use of a test kit for inorganic phosphate (Merck). $P_{i}$ was measured after a 30 -min incubation in a medium which did not contain PEP, $\mathrm{NADH}, \mathrm{PK}$, and $\mathrm{LDH}$, but was otherwise unchanged.

\section{Artificial media}

In order to investigate as to whether the $\mathrm{Na}$ pump and the $\mathrm{Cl}$ pump are coupled to each other, several artificial media were employed. Based on brackish water of $9 \% \mathrm{~S}$, which also served as low salinity control, $\mathrm{Na}$ and $\mathrm{Cl}$ were increased selectively by addition of $\mathrm{Na}_{2} \mathrm{SO}_{4}$ or $\mathrm{MgCl}_{2}$ respectively, in amounts to reach a final density equivalent to a salinity of $35 \%$, which was measured aerometrically. $\mathrm{MgSO}_{4}$ was added in another medium in the same way, to serve as a control with increased salinity, but $\mathrm{Na}$ and $\mathrm{Cl}$ 
concentrations equivalent to low salinity water. A final control was normal seawater of $35 \%$.

\section{Determination of inorganic constituents}

Hemolymph was obtained by puncturing the membrane at the base of a walking leg of the crab by means of hypodermic needle. After centrifugation for $5 \mathrm{~min}$ at $2000 \mathrm{~g}$, the supernatant serum was stored at $-25^{\circ} \mathrm{C}$ until analysis. $\mathrm{Na}, \mathrm{K}, \mathrm{Ca}$, and $\mathrm{Mg}$ in serum and ambient media were determined by means of atomic absorption spectrophotometry (AAS 300, Perkin Elmer) after sample dilution with Herrmann dilution medium (Merck). Concentrations of $\mathrm{Cl}$ were measured with a Cl-electrode (Orion).

\section{RESULTS}

\section{Dynamics of Na-K-ATPase activity after salinity change}

Following transfer of shore crabs from 35 to $10 \% \mathrm{~S}$, the activity of the Na-K-ATPase in Gill 8 steadily increased to reach new steady-state levels 2 to 3 weeks after transfer (Fig. 1). Gill 8 was chosen throughout this study as representative of the 3 posterior Gills 7 to 9 with pronouncedly higher activities in comparison to anterior gills (Siebers et al.,

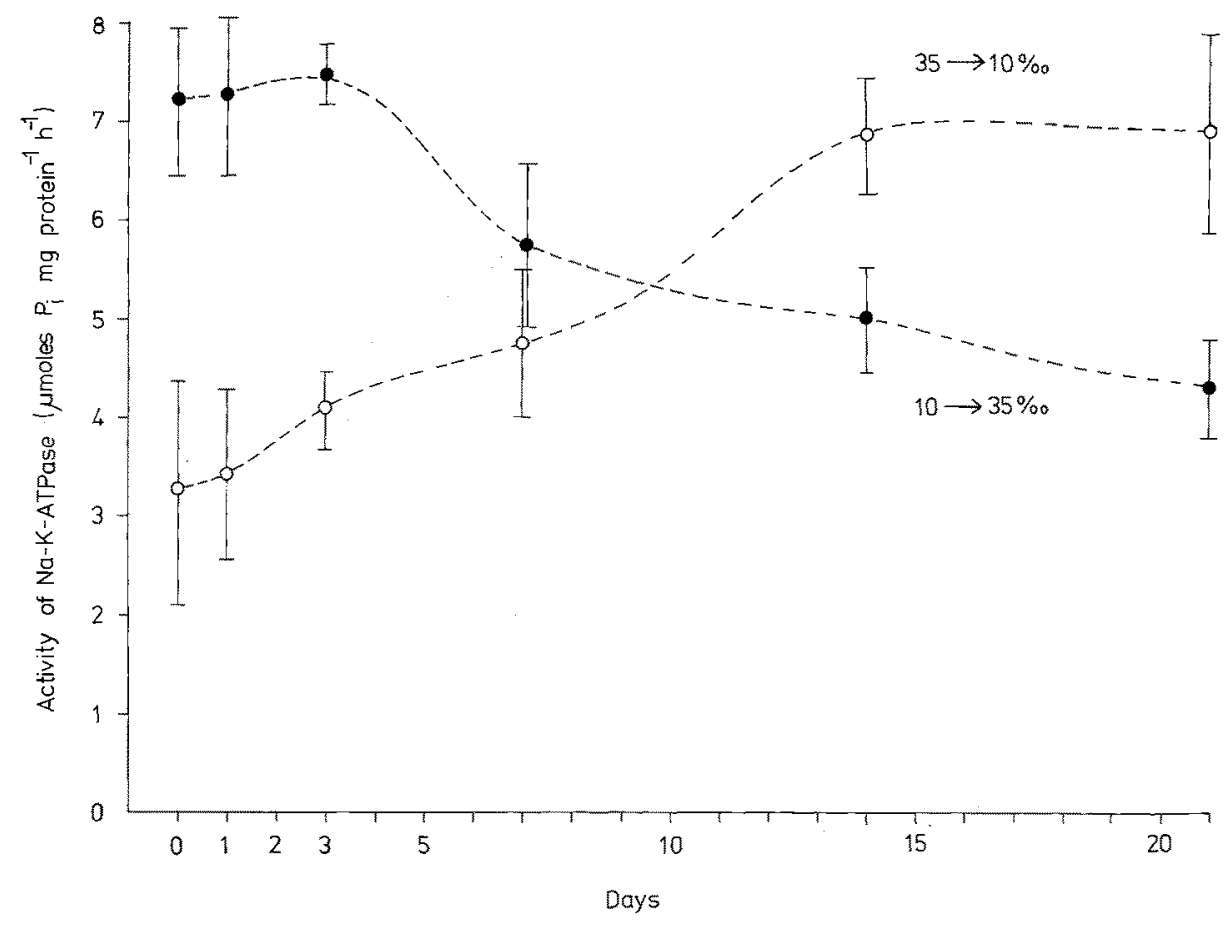

Fig. 1. Carcinus maenas: Dynamics of Na-K-ATPase activity in Gill 8 following salinity change from 10 to $35 \%$ (closed circles) and from 35 to $10 \%$ (open circles). Circles and bars represent means and standard deviations taken from a sample size of 5 crabs 
1982). After transfer of crabs from 10 to $35 \% \mathrm{~S}$, the activity decreased in about the same period.

\section{Substrate inhibition of Na-K-ATPase activity}

The activity of the Na-K-ATPase in Gill 8, incubated at varying concentrations of $\mathrm{Na}$, did not show saturation kinetics (Fig. 2). Instead, a maximum was observed at $75 \mathrm{mM}$

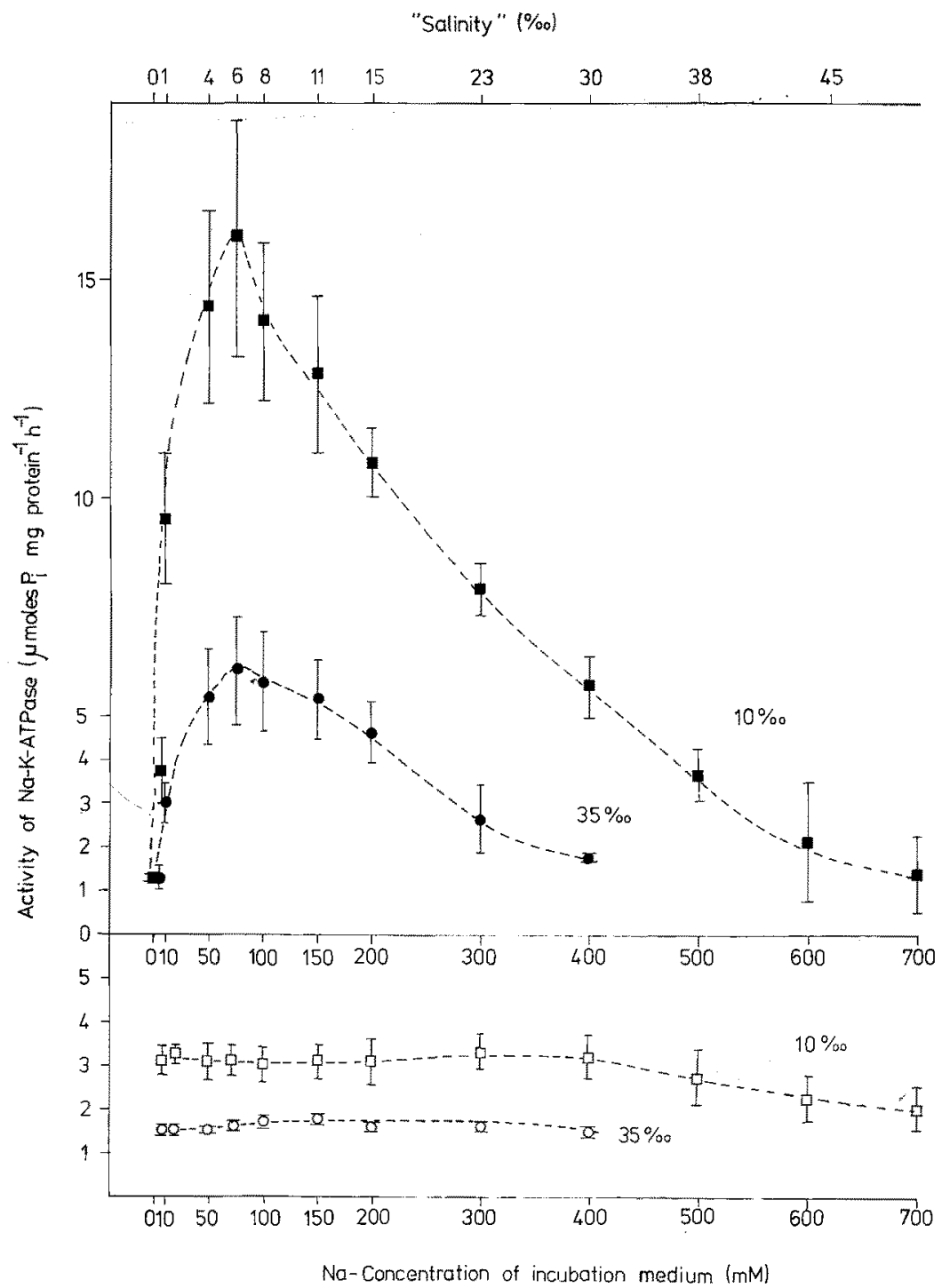

Fig. 2. Carcinus maenas: Activity of Na-K-ATPase and unspecific ATPases in Gill 8 of crabs maintained for 5 to 6 weeks in $10 \%$ (squares) and $35 \% \mathrm{~S}$ (circles) in relation to the $\mathrm{Na}$ concentration of the incubation medium. Symbols and bars represent means and standard deviations taken from a sample size of 4 crabs 
Na reached after a steep increase at low $\mathrm{Na}$ concentrations of between 0 and $75 \mathrm{mM}$. This maximum was followed by a slower decrease along with rising Na concentrations. Activity reached minimum levels between 400 and $700 \mathrm{mM} \mathrm{Na}$.

Activity of the unspecific ATPases, including all other ATP splitting enzymes, was not dependent on the $\mathrm{Na}$ concentration of the incubation medium, but remained constant over the range of $\mathrm{Na}$ concentrations tested (Fig. 2). The activity of unspecific ATPases did, however, depend on the salinity of the medium used for adaption of the crabs. Activity of unspecific ATPases in gills of crabs acclimated to $10 \% \mathrm{~S}$ (about $3 \mathrm{mM} \mathrm{P}_{\mathrm{i}} \mathrm{mg}$ protein $^{-1} \mathrm{~h}^{-1}$ ) exceeded the activity in crabs from $35 \% \mathrm{~S}$ (about $1.5 \mathrm{mM} \mathrm{P}_{\mathrm{i}} \mathrm{mg}$ protein $^{-1} \mathrm{~h}^{-1}$ ) by a factor of 2. Activity of unspecific ATPases was lower than that of the sodium pump, amounting to only about $19 \%$ of total ATPase activity, when compared to the Na-K-ATPase at $75 \mathrm{mM} \mathrm{Na}$.

\section{Distribution of ions between medium and hemolymph}

Controls kept in brackish water of $9 \% \mathrm{~S}$ hyperregulated $\mathrm{Na}, \mathrm{K}, \mathrm{Ca}$, and $\mathrm{Cl}$ (Table 1, Fig. 3). Mg concentrations, on the other hand, were hyporegulated. Crabs kept in sea

Table 1. Carcinus maenas: Concentrations of $\mathrm{K}, \mathrm{Ca}$, and $\mathrm{Mg}$ in serum samples and ambient media selectively enriched with $\mathrm{Na}$ or $\mathrm{Cl}$. Concentrations in the serum are means and standard deviations taken from a sample size or 5 crabs kept at least 3 days in the media indicated, before hemolymph samples were taken

\begin{tabular}{|c|c|c|c|c|c|c|c|}
\hline \multirow{2}{*}{ Medium } & \multirow{2}{*}{$\begin{array}{l}\text { Number } \\
\text { of crabs }\end{array}$} & \multicolumn{2}{|c|}{$\mathrm{K}(\mathrm{mM})$} & \multicolumn{2}{|c|}{$\mathrm{Ca}(\mathrm{mM})$} & \multicolumn{2}{|c|}{$\mathrm{Mg}(\mathrm{mM})$} \\
\hline & & $\begin{array}{l}\text { me- } \\
\text { dium }\end{array}$ & se- & $\begin{array}{l}\text { me- } \\
\text { dium }\end{array}$ & $\begin{array}{l}\text { se- } \\
\text { rum }\end{array}$ & $\begin{array}{l}\text { me- } \\
\text { dium }\end{array}$ & $\begin{array}{l}\text { se- } \\
\text { rum }\end{array}$ \\
\hline $\begin{array}{l}9 \% \text { sea water, } \\
\text { Control, pH } 7.6\end{array}$ & 10 & 3 & $7 \pm 1$ & 4 & $8 \pm 2$ & 13 & $6 \pm 1$ \\
\hline $\begin{array}{l}9 \% \text { sea water }+240 \mathrm{mM} \\
\mathrm{MgCl}_{2}, \mathrm{pH} 7.2\end{array}$ & 4 & 3 & $6 \pm 1$ & 4 & $18 \pm 2$ & 246 & $97 \pm 21$ \\
\hline $\begin{array}{l}9 \% \text { sea water }+184 \mathrm{mM} \\
\mathrm{Na}_{2} \mathrm{SO}_{4}, \mathrm{pH} 7.2\end{array}$ & 10 & 3 & $5 \pm 1$ & 4 & $6 \pm 2$ & 15 & $5 \pm 2$ \\
\hline $\begin{array}{l}9 \% \text { sea water }+228 \mathrm{mM} \\
\mathrm{Mg} \mathrm{SO}_{4}, \mathrm{pH} 7.4\end{array}$ & 6 & 3 & $6 \pm 1$ & 4 & $10 \pm 1$ & 195 & $22 \pm 5$ \\
\hline $\begin{array}{l}35 \% \text { sea water, Control, } \\
\mathrm{pH} 7.8\end{array}$ & 6 & 12 & $12 \pm 2$ & 14 & $13 \pm 2$ & 55 & $21 \pm 3$ \\
\hline
\end{tabular}

water of $35 \% \mathrm{~S}$ also hyporegulated $\mathrm{Mg}$ levels in hemolymph, while $\mathrm{Na}, \mathrm{K}, \mathrm{Ca}$, and $\mathrm{Cl}$ were isoionic in blood and medium.

\section{Addition of $\mathrm{MgCl}_{2}$}

In order to increase, selectively, the $\mathrm{Cl}$ concentration in brackish water of $9 \% \mathrm{~S}$, without changing $\mathrm{Na}$ levels, $240 \mathrm{mM} \mathrm{MgCl}_{2}$ were added. This amount increased the aerometrically measured salinity from $9 \%$ to about $35 \%$. The ambient medium thus obtained signals a Na concentration to the crab equivalent to an external salinity of $9 \%$, while osmotic pressure and $\mathrm{Cl}$ signal a salinity of $35 \%$. 
Addition of $\mathrm{MgCl}_{2}$ had - as anticipated - no influence on blood Na levels (295 \pm $48 \mathrm{mM})$, which were hyperregulated as in control crabs from $9 \% \mathrm{~S}$ (317 $\pm 42 \mathrm{mM} \mathrm{Na}$ in blood, $129 \mathrm{mM}$ in ambient water). Blood levels of $\mathrm{Cl}(571 \pm 25 \mathrm{mM})$ were approximately isoionic to medium concentrations $(603 \mathrm{mM})$.

The distribution of $\mathrm{K}$ was unchanged when compared to controls from $9 \% \mathrm{~S}$, indicating non-coupling between $\mathrm{K}$ and $\mathrm{Cl}$ transport. The high $\mathrm{Mg}$ levels of $246 \mathrm{mM}$ in external medium were effectively hyporegulated to hemolymph concentrations of $97.1 \pm 21.2 \mathrm{mM}$, a value less than half the ambient concentrations. This finding is consistent with hyporegulation of $\mathrm{Mg}$ to half the ambient levels in control crabs kept in 9 and $35 \% \mathrm{~S}$.

Most interesting is the unexpectedly high degree of hyperregulation of $\mathrm{Ca}$ in Mg-enriched medium to blood levels of $17.5 \pm 2.3 \mathrm{mM}$ in comparison to the ambient concentration of $3.7 \mathrm{mM}$, that means by a factor of 5 instead of 2 in controls from $9 \% \mathrm{~S}$.

\section{Addition of $\mathrm{Na}_{2} \mathrm{SO}_{4}$ and $\mathrm{MgSO}_{4}$}

In order to increase, selectively, the $\mathrm{Na}$ concentration of the medium, without changing $\mathrm{Cl}$ levels, $184 \mathrm{mM} \mathrm{Na}_{2} \mathrm{SO}_{4}$ were added. While blood $\mathrm{Na}(531 \pm 62 \mathrm{mM}$ ) was isoionic to ambient $\mathrm{Na}(518 \mathrm{mM}), \mathrm{Cl}$ was hyperregulated to $278 \pm 48 \mathrm{mM}$ compared to ambient $\mathrm{Cl}$, which amounted to $136 \mathrm{mM}$ (Fig. 3). Addition of $\mathrm{Na}_{2} \mathrm{SO}_{4}$ virtually did not

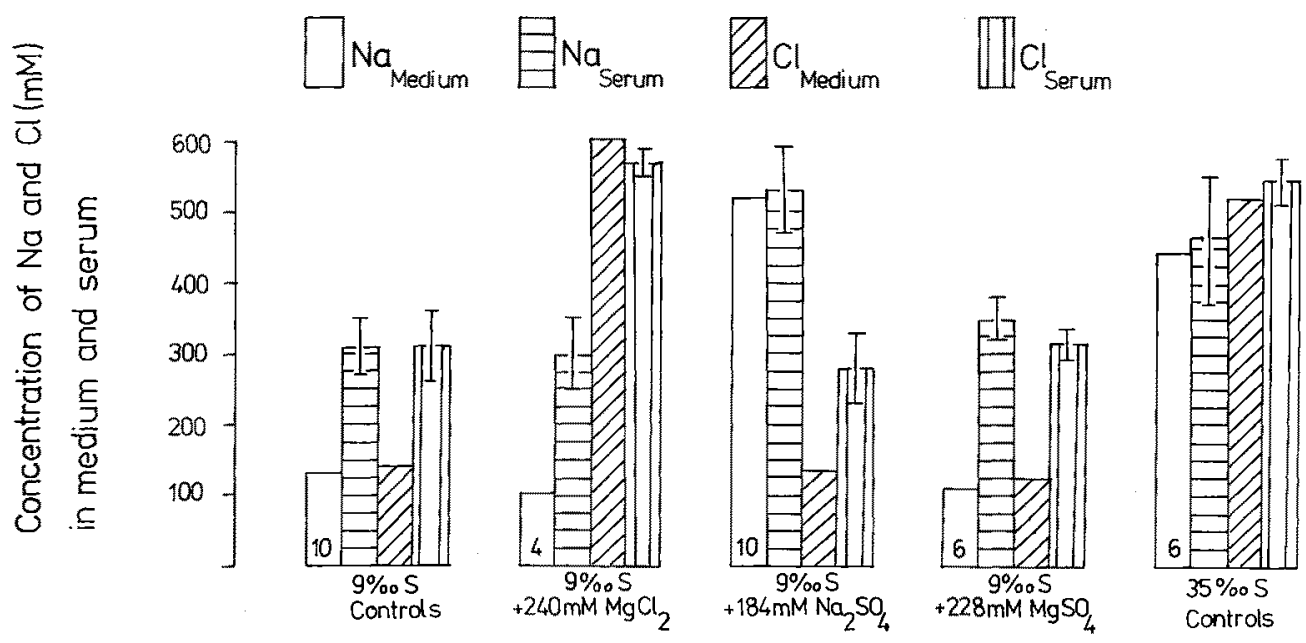

Fig. 3. Carcinus maenas: Concentrations of $\mathrm{Na}$ and $\mathrm{Cl}$ in serum samples and ambient media selectively enriched with $\mathrm{Na}$ or $\mathrm{Cl}$. Concentrations in the serum are means and standard deviations taken from a sample size of 5 crabs kept at least 3 days in the media indicated, before hemolymph samples were taken

change the distribution between blood and medium of $\mathrm{CI}, \mathrm{Ca}$, and $\mathrm{Mg}$ when compared to controls kept in $9 \% \mathrm{~S}$.

Notably, $K$, which should be pumped at reduced rates by the Na-K-ATPase under conditions of $\mathrm{Na}$ equilibrium, had its lowest value $(5 \pm 1 \mathrm{mM})$ in comparison to $\mathrm{K}$ levels found in other media, but was still hyperregulated. 
Addition of $228 \mathrm{mM} \mathrm{MgSO}_{4}$ did not significantly influence the distribution between blood and medium of $\mathrm{Na}, \mathrm{Cl}, \mathrm{K}$, and $\mathrm{Ca}$. However, the $\mathrm{Mg}$ concentration in blood $(22.2 \pm 5.1 \mathrm{mM})$ was reduced by a remarkably high factor of 9 in comparison to the value of the medium (195 $\mathrm{mM}$ ).

\section{DISCUSSION}

\section{Dynamics of the Na-K-ATPase activity after salinity change}

We reported that after a salinity change from 10 to $35 \%$ and vice versa, a period of 2 to 3 weeks elapsed before the Na-K-ATPase in the gills of Carcinus maenas had attained new salinity-specific steady-state concentrations. This finding suggests that if the $\mathrm{Na}-\mathrm{K}-$ ATPase plays a role in $\mathrm{Na}$ regulation, the adaptive nature of enzyme-activity, as a measure of enzyme amounts or concentration, may only be of significance under relatively constant external salinities, encountered, for example, in the North Sea at salinities ranging from 30 to $33 \%$ and in the central and western Baltic at salinities between 8 and $20 \%$. If the differences we found in experiments in concentrations of $\mathrm{Na}$ K-ATPase activity in gills also exist in crabs inhabitating North Sea and Baltic habitats, an assumption which still has to be proved, then Baltic crabs may - due to increased activity of the Na pump - be more able to hyperregulate Na than North Sea specimens with passive distribution of $\mathrm{Na}$ between internal and external media.

Reports on the dynamics of Na-K-ATPase activity following a salinity change are controversial. Significant responses within a few hours were observed in the blue crab Callinectes sapidus (Towle et al., 1976), the hermit crab Clibanarius vittatus (Sabourin \& Saintsing, 1980), and the killifish Fundulus heteroclitus (Towle et al., 1977). Responses were observed within several days in the blue crab Callinectes sapidus (Almeida \& Pritchard, 1980), in the coho salmon Onchorynchus kisutch (Folmar \& Dickhoff, 1979), and in the eel, Anguilla japonica (Ho \& Chan, 1980).

\section{Activation and inhibition of Na-K-ATPase by Na}

The pronounced activity maximum of the Na-K-ATPase at an ambient Na concentration of $75 \mathrm{mM}$ is indicative of drastic substrate inhibition at higher $\mathrm{Na}$ levels. A peak at $75 \mathrm{mM} \mathrm{Na}$ was found in the gills of crabs adapted to both salinities (10 and $35 \%$ ), suggesting that ambient salinity did not modify the affinity for Na. Peak height, however, was reduced in individuals adapted to normal seawater, confirming previous results (Siebers et al., 1982) that Na-K-ATPase activity in the gills of shore crabs, maintained for several weeks at $35 \% \mathrm{~S}$, decreased to less than half the activity encountered in crabs form $10 \%$.

Na concentrations resulting in highest and lowest activity correspond to environmental Na levels, suggesting that highest activity of the $\mathrm{Na}$ pump, observed at $75 \mathrm{mM}$ $\mathrm{Na}$, is displayed at a concentration characteristic of the lower environmental salinity limit (ca 6 to $8 \%$ ) for $C$. maenas. Here, the highest degree of hyperregulation is found. With increasing ambient salinities exceeding $30 \%$, the Na pump is inhibited by its own substrate Na. Here, active uptake of Na may be depressed resulting in passive distribution between hemolymph and habitat. 
The remarkably strong substrate inhibition may represent the basic mechanism providing instant activity responses to sudden ambient salinity changes in estuaries and tide pools. It is known that after sudden environmental salinity change, inorganic hemolymph constituents and osmotic pressure in C. maenas attain their new steady-state levels within 1 to 2 days (Siebers et al., 1972). This relatively fast response may also be based on the substrate activation and inhibition properties of the monovalent cation pump. It must be noted that in $\mathrm{C}$. maenas intracellular $\mathrm{Na}$ concentrations in the gill epithelial cell, which supposedly control Na-K-ATPase activity, are not known up-todate.

The finding that in the gills of C. maenas Na-K-ATPase amounts to about $80 \%$ of total ATPases (Fig. 2) confirms previous results on high proportions of Na-K-ATPase in ion transporting tissues (Siebers et al., 1982). At an ambient salinity of $10 \%$, the activity of the unspecific ATPases was increased by a factor of about 2 when compared with crabs kept in $35 \%$ (Fig. 2). These data correspond to increased metabolic activity in shore crabs inhabiting dilute media, indicated by increased $\mathrm{O}_{2}$ uptake and elevated levels of serum protein and hemocyanin (Theede, 1964; Siebers et al., 1972). In this context, thickening of the gill epithelia due to surface enlargements was described for the fiddler crab Uca pugilator upon transfer to low salinity by Graszynski \& Drews (1981).

\section{Distribution of ions between medium and blood}

Carcinus maenas hyperregulated most of the dominating ions $(\mathrm{Na}, \mathrm{K}, \mathrm{Ca}, \mathrm{Cl})$, when inhabiting dilute media. In normal seawater, these ions were in equilibrium with external medium. $\mathrm{Mg}$, on the other hand, was effectively hyporegulated in all media containing between 13 and $256 \mathrm{mM} \mathrm{Mg}$. For comparison, the $\mathrm{Mg}$ concentration in sea water is $53 \mathrm{mM}$ (Whitfield, 1981).

Since urine : blood (U/B) concentration ratios for $\mathrm{Na}, \mathrm{K}$, and $\mathrm{Cl}$ in $\mathrm{C}$. maenas are close to 1 in media between 9 and $35 \% \mathrm{~S}$, indicating that the shore crab is unable to produce dilute or concentrated urine (Riegel \& Lockwood, 1961; Zanders, 1980), hyperregulation of these ions must exclusively be based on active uptake mechanisms across the gill epithelium. U/B concentration ratios for Ca between 1.2 and 1.5 (Riegel \& Lockwood, 1961; Zanders, 1980) and the distribution of ionized Ca in shore crabs kept in seawater of $9 \% \mathrm{~S}_{\text {s }}$ amounting to $2.3 \mathrm{mM}$ (86\% ionized) in brackish water and about $4.7 \mathrm{mM}(77 \%$ ionized) in hemolymph (Greenaway, 1976), suggest the presence of active Ca uptake. Hyporegulation of $\mathrm{Mg}$ in crabs adapted to seawater mainly results from active secretion into the urine. Thus, $\mathrm{Mg}$ concentration in urine is increased 4 to 8 fold when compared to Mg concentration in the blood (Riegel \& Lockwood, 1961; Zanders, 1980).

In their review on Na-coupled $\mathrm{Cl}$ transport by epithelial cells, Frizzell et al. (1979) argue that currently there is no compelling evidence for primary active transport of $\mathrm{Cl}$ directly linked to a source of metabolic energy in animal epithelia. Instead, uphill $\mathrm{Cl}$ transport at the luminal membrane is an electrically neutral $\mathrm{Na}$ co-transport step which is widely distributed throughout the animal kingdom.

In order to investigate the question as to whether uphill movements of $\mathrm{Na}$ and $\mathrm{Cl}$ are directly coupled in the gills of shore crabs, we employed brackish water of $9 \% \mathrm{~S}$ in which either $\mathrm{Na}$ or $\mathrm{Cl}$ was increased without changing the concentration of the other ion. 
In the medium selectively enriched by $\mathrm{Cl}\left(9 \% \mathrm{~S}+240 \mathrm{mM} \mathrm{MgCl}_{2}\right.$ ) (Fig. 3), hemolymph- $\mathrm{Cl}$ was in equilibrium with external $\mathrm{Cl}$, a distribution observed in normal sea water, which does not require biological energy. However, low external $\mathrm{Na}$, comparable to its concentration in $9 \% \mathrm{~S}$, was effectively hyperregulated.

In the medium selectively enriched by $\mathrm{Na}\left(9 \% \mathrm{~S}+184 \mathrm{mM} \mathrm{Na}_{2} \mathrm{SO}_{4}\right)$, $\mathrm{Na}$ was passively distributed while $\mathrm{Cl}$ was hyperregulated. These high concentrations of $\mathrm{Na}$ would certainly inhibit the Na-K-ATPase to very low activities (Fig. 2). Were $\mathrm{Cl}$ transport coupled to such low Na-K-ATPase activity, the observed effective hyperregulation of $\mathrm{Cl}$ would most probably not result. The data reported therefore suggest that under appropriate conditions the normally uphill translocations of $\mathrm{Na}$ and $\mathrm{Cl}$ can take place independently of each other, a conclusion directly confirming the findings by Zanders (1981) in Carcinus gills.

In conclusion, the adaptive nature of the concentrations of Na-K-ATPase in the gills of Carcinus maenas and various other euryhaline decapods with respect to ambient salinity implies a central role of the Na pump in crabs hyperregulating their body fluids when inhabiting dilute media. However, subtle knowledge of its functioning is still lacking, and the mode of operation in fresh water inhabitants as well as the potential coupling to active uptake of $\mathrm{Cl}$ deserve further investigation.

Acknowledgements. This research is part of the program "Stoffwechsel unter Extrembedingungen" of the Deutsche Forschungsgemeinschaft, the grant for which (Sie 295/1-2) is gratefully accepted. We thank D. Weichart for skilful technical assistance.

\section{LITERATURE CITED}

Almeida, A. F. \& Pritchard, J. B., 1980. Isolation and characterization of Na-K-ATPase induced in crabs, Callinectes sapidus exposed to osmotic stress. - Physiologist, Wash. 23, 175 (Abstr.).

Folmar, L. C. \& Dickhoff, W. W., 1979. Plasma thyroxine and gill Na-K-ATPase changes during seawater acclimation of coho salmon, Onchorynchus kisutch. - Comp. Biochem. Physiol. 63A, 329-332.

Frizzell, R. A., Field, M. \& Schultz, S. G., 1979. Sodium-coupled chloride transport by epithelial tissues. - Am. J. Physiol. 236, 71-78.

Graszynski, K. \& Drews, G., 1981. Beteiligung der einzelnen Kiemen an der hyperosmotischen Regulation der Winkerkrabbe Uca pugilator, - Verh. dt. zool. Ges, 1981, 45.

Greenaway, P., 1976. The regulation of haemolymph calcium concentration of the crab Carcinus maenas (L.). - J. exp. Biol. 64, 149-157.

Ho, S.-M. \& Chan, D. K. O., 1980. Branchial ATPase and ionic transport in the eel, Anguilla japonica - I. Na-K-ATPase. - Comp. Biochem. Physiol. 66B, 255-260.

Riegel, J. A. \& Lockwood, A. P. M., 1961. The role of the antennal gland in the osmotic and ionic regulation of Carcinus maenas. - J. exp. Biol. 38, 491-499.

Sabourin, T. D. \& Saintsing, D. G., 1980. Transport ATPases in the osmoregulating hermit crab Clibanarius vittatus. - Physiologist, Wash. 23, 175 (Abstr.).

Siebers, D., Lucu, C., Sperling, K. R. \& Eberlein, K., 1972. Kinetics of osmoregulation in the crab Carcinus maenas. - Mar. Biol, 17, 291-303.

Siebers, D., Leweck, K., Markus, H. \& Winkler, A., 1982. Sodium regulation in the shore crab Carcinus maenas as related to ambient salinity. - Mar. Biol. 69, 37-43.

Theede, H., 1964. Physiologische Unterschiede bei der Strandkrabbe Carcinides maenas L. aus der Nord- und Ostsee. - Kieler Meeresforsch. 20, 179-191.

Towle, D. W., Palmer, G. E. \& Harris, J. L., 1976. Role of gill Na-K-dependent ATPase in acclimation of blue crabs (Callinectes sapidus) to salinity. - J. exp. Zool. 196, 315-332. 
Towle, D. W., Gilman, M. E. \& Hempel, J. D., 1977. Rapid modulation of Na-K-dependent ATPase activity during acclimation of the killifish Fundulus heteroclitus to salinity change. $-J$. exp. Zool. $202,179-186$.

Whitfield, M. 1981. The world ocean - mechanism or machination. - Interdisciplinary Sci. Rev. 6 , $12-35$.

Zanders, I. P., 1980. Regulation of blood ions in Carcinus maenas (L.). - Comp. Biochem. Physiol. $65 A, 97-108$.

Zanders, I. P., 1981. Control and dynamics of ionic balance in Carcinus maenas (L.). - Comp. Biochem. Physiol. 70A, 457-468. 